\title{
A Case of Malignant Lymphoma Suspected as Peritoneal Metastasis from Laryngeal Carcinoma
}

\author{
Kenichi Mori, Masami Ohnishi, Hiroki Takahashi and Yuzuru Sakaida
}

\begin{abstract}
We report herein on a rare case of double primary malignant tumors composed of squamous cell carcinoma of the larynx and malignant lymphoma. The patient was a 60-year-old man with the chief complaints of swelling on the right side of his neck and hoarseness. Endoscopic examination demonstrated a massive tumor on the right supraglottic tissue. The accumulation of fluorodeoxyglucose was seen in the larynx, the cervical lymph nodes, the spleen, and the intraperitoneal lymph nodes. Supraglottic squamous cell carcinoma of the larynx (T4aN2bM1) was diagnosed. Two courses of chemotherapy was first performed, and the intraperitoneal lesion almost disappeared on PET-CT. After the third course of chemotherapy, concurrent chemoradio-therapy was administered. As a result, the right supuraglottic tumor had completely disappeared. However, an intraperitoneal lymph node had developed. The patient underwent laparotomy, and the histopathological diagnosis was diffuse large B-cell lymphoma. The patient was treated with R-CHOP. There was no recurrence of laryngeal carcinoma observed for 9 months until he died of malignant lymphoma.
\end{abstract}

Keywords : malignant lymphoma, laryngeal carcinoma, intraperitoneal tumor

\section{References}

1) Satoh S, Kakizoe A, Uchida M, et al. : Two cases of squamous cell carcinoma of the head and neck with concurrent nonHodgkin lymphoma. Pract Otol (Kyoto) 96: 73-78, 2003.

2) 宮原 裕, 家根旦有, 鶴田至宏, 他: 喉頭癌の臨床的検討. 日耳鼻会報 105：790-798, 2002.

3）大川智彦, 喜多みどり, 田中真喜子, 他：頭頸部癌におけ る重複癌症例の検討。日癌治療会誌 24: 957-965, 1989.

4）伊藤恵子, 久保田彰, 佃守, 他: 頭頸部領域の重複癌. 癌の臨 38: 675-678, 1992.

5）安原秋夫, 石崎久義, 森田浩史, 他：当科における頭頸部 重複癌症例の臨床統計学的観察。日耳鼻会報 95：686-696, 1992.

6）吉野邦俊：頭頸部癌における重複癌. 日耳鼻専門医通信 44: 8-9, 23, 1995.
7) Takahashi E, Suzuki T, Ito Y, et al. : Hemangiopericytoma of the parapharyngeal space. Pract Otol (Kyoto) 89: 1383-1388, 1996.

8）斉川雅久, 海老原敏: 頭頸部外科医の立場から見た重複癌. 癌の臨 44: 1351-1358, 1998.

9）兼安祐子，喜多みどり，小島菜穂子，他：頭頸部三重複癌 症例の臨床的検討．頭頸部腫瘍 25：112-117, 1999.

10）篠 昭男, 吉原俊雄: 当科における頭頸部重複癌症例の臨 床統計的検討.耳鼻と臨 45：332-336, 1999 .

11）中溝宗永：頭頸部管腔癌における重複癌（会議録）日癌治 療会誌 22：2122, 1987.

12) 酒井邦夫, 末山博男, 斎藤眞理, 他 : 覀性リンパ腫におけ る重複癌. 癌の臨 30：1524-1529, 1984.

13）宮村朋孝, 福家智仁, 富岡利文, 他：喉頭癌根治術の際に 発見された偶発性悪性リンパ腫. 耳鼻臨床 補 120: 73, 2007.
Department of Otolaryngology, Head and Neck Surgery, Ogaki Municipal Hospital
Corresponding Author Address : Kenichi Mori t2111030@gmail.com 


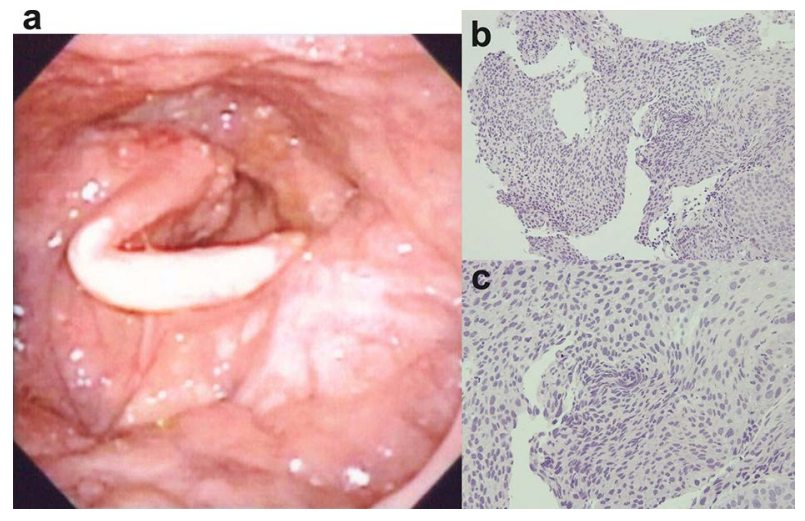

a: The endoscopic view showing a tumor in the right aryepiglottic fold

b, c: Histopathologic examination showing proliferation of atypical cell with high nuclear-cytoplasmic ratio (H\&E; original magnification b: $\times 100$, c: $\times 400$ )

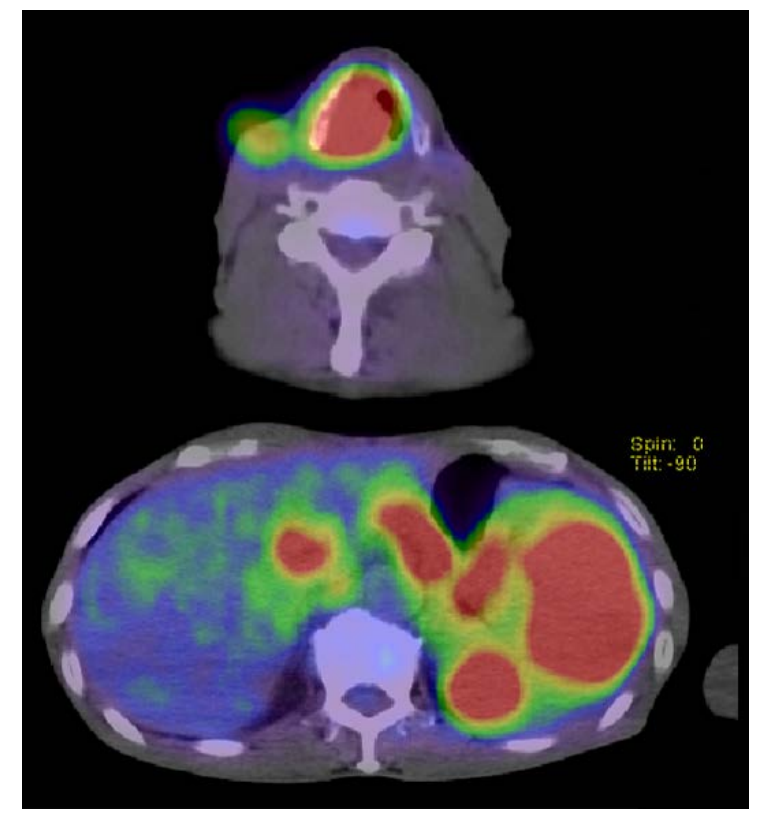

PET-CT before treatment showing high uptake in the larynx, bilateral neck lymph nodes, spleen, and epigastric lymph nodes

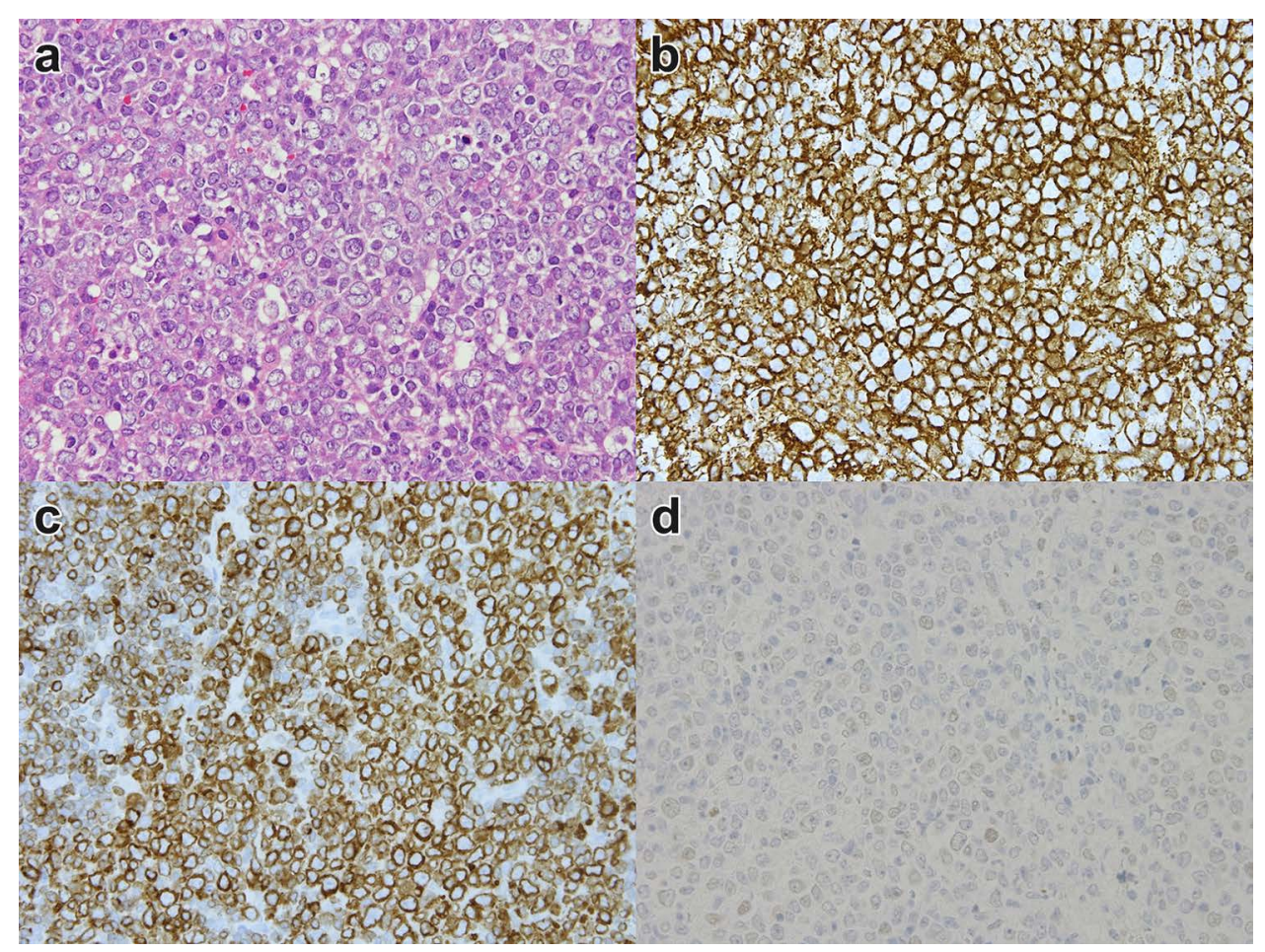

Histopathologic examination of the abdominal lymph node showing dense proliferation of atypical cell with anisonucleosis, compatible with malignant lymphoma (a: H\&E, $\times 400$, b: CD20, $\times 400$, c: BCL-2, $\times 400$, d: BCL-6, $\times 400)$ 